\title{
EFFECT OF FLOOD EVENT ON WATER QUALITY
}

\author{
Kamalanandhini. $\mathbf{M}^{1, *}$, Kalaivizhi. $\mathbf{R}^{2}$, Golda Percy. VP${ }^{1}$, Srividhya. $\mathbf{S}^{1}$, \\ Dheepak. $S^{1}$ and $K$. Thiyaneshwaran. $K^{1}$ \\ ${ }^{1}$ Department of Civil Engineering, SRM Institute of Science and Technology, \\ Kattankulathur - 603203, Tamilnadu, India \\ ${ }^{2}$ Department of Chemistry, SRM Institute of Science and Technology, \\ Kattankulathur - 603203, Tamilnadu, India \\ *E-mail: nandhinimohan90@gmail.com
}

\begin{abstract}
Rapid urbanization and climate change lead to a rise in the frequency of dangerous water-related happenings such as flood and drought. This causes a negative impact on the environment, economy and human health. Depending upon the local conditions and sanitation facilities of an area, the flood water can contaminate drinking water sources such as surface water, groundwater, and even the water distribution systems. The study was carried out to examine the impact of a flood event on water quality after 2015 flood in Kancheepuram district. Groundwater samples from Urapakkam, Guduvancheri, Kattankulathur, and Maraimalai Nagar were collected and tested for analyzing the quality of water in these regions. Different physio-chemical parameters were compared with the permissible limits formulated by the World Health Organization - Drinking water quality standards to assess the impact of the flood on water quality. During the flood, the quality of water was considerably good, but due to human activities in the region, the quality of water deteriorated post-flood.
\end{abstract}

Keywords: Flood, Contamination, Physio-chemical Parameters, Water Quality, WHO Standards

(c) RASĀYAN. All rights reserved

\section{INTRODUCTION}

Water is an indivisible resource. The large ecological system consists of rainfall, ponds, rivers, lakes, and groundwater. The expansion of economic activities unavoidably leads to the increasing demand of water for different diverse purposes. Some of them are domestic, agricultural, industrial, recreation, navigation, etc., Water scarcity is a region and season specific problem. It is imperious that water as a scarce and precious resource should be conserved and managed on an environmentally sound basis. ${ }^{1}$ One of the earth's widely distributed sources of water is groundwater. It is considered as a minimum polluted, compared to other sources, but studies show that it is free from suspended solids but not from pollution. ${ }^{2}$ Water resources cover nearly $70 \%$ of the planet, and upon which all life depends. Water sources are the centers of life throughout the history of the natural world, providing nutrition and habitat for plants and animals. ${ }^{3}$ Anthropogenic contaminations such as municipal wastewater, effluent from industries, fertilizer used for agriculture, and landfill causes deterioration of water quality. Since there is an increasing demand for potable water and lack of surface water, there is an increase in the importance of groundwater every day. ${ }^{4}$ The physiochemical parameters of water determine the water quality. It is very complex since water is a complex medium basically related to the earth. ${ }^{5}$

Groundwater is widely used for agriculture, industry and domestic purposes. It is a rechargeable source and has an intrinsic advantage upon surface water since it is pure and has low evaporation loss. The geochemical reaction controls the groundwater chemistry which takes place along the flow of water. Groundwater chemistry determines the use for domestic, industrial and irrigation needs. The interface between groundwater and minerals present in aquifer greatly controls groundwater chemistry. The change in the chemical composition of groundwater is due to the hydro-geochemical process with respect to time and space. This process helps to obtain perception into the soil-water interaction. ${ }^{6}$ The demand for

Rasayan J. Chem., 12(2), 849-854(2019)

http://dx.doi.org/10.31788/RJC.2019.1225232

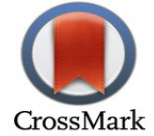


groundwater has significantly increased in arid and semi-arid regions where it is a major source. This is due to population growth, whereas there was a decrease in an average of rainfall, so there was a demand for groundwater. ${ }^{7}$

The changes in the hydrological regime will be considered upon a review on surface water quality. ${ }^{8}$ Apart from the other physical and chemical parameters, the health hazards parameters such as Total dissolved solids, Fluoride and Nitrate have been given more priority as it affects the human health system. ${ }^{9}$ Water used for livestock must be of the best quality in order to avoid them exposed to various diseases or getting poisoned by toxic substances. The water quality parameters for drinking water are same for both livestock and human even though the allowable levels of salinity and total suspended solids vary. ${ }^{10}$ Drought and flood affect massive areas of the country, exceeding the boundaries.

Climate Change is the change in temperature, water stress, precipitation, cyclones, flood, and drought. ${ }^{1}$ Major flood experiences abundant economic loss, particularly in the densely populated region. The most damaging phenomena of all natural risks are flooding which affects the socio-economic aspects of the population. The spread of communicable diseases through water, the devastation of habitats, loss of agriculture and properties and dilapidation in the water quality are some of the negative impacts of flood. Flooding increases the risk of life by causing water pollution on the surface and this is due to the overloading of rivers and drainage. ${ }^{11}$ The major issue in the groundwater study is water quality analysis. Variation in the quality of groundwater for a region is due to the physiochemical parameter which is influenced by anthropogenic activities and geological formations. Groundwater is the harmless water among the various sources, for drinking and other purposes. ${ }^{12}$

\section{Study area Demarcation}

\section{EXPERIMENTAL}

The region selected for the research is Kancheepuram district which is situated at North - East of Tamilnadu. The pre-monsoon rainfall of Kancheepuram district is almost uniform. Excess rainfall is received in the coastal regions than the interior. Since the district is dependent on monsoon rains, failure of which leads to distress condition. The main donors are the south-west and the north-east monsoon. The district receives rainfall of $1200 \mathrm{~mm}$ during monsoon season. Palar river runs through the district and most of the year it remains dry. There are few hills of considerable elevation and the southern part contains some small hills. 23,586 hectares are covered by forest in the district. The region selected for the study covers Urapakkam, Guduvancheri, Potheri, Kattankulathur, and Maraimalai Nagar regions of Kancheepuram District. These regions have been much affected by the flood and the groundwater has been deteriorated considerably.

\section{Testing of Water Samples}

For the selected sources, water samples are collected after pumping for some depth, to ensure the sample represents groundwater source. To achieve a characteristic drawdown of groundwater source it is necessary to pump at a specified rate. The water is collected in containers and closed with airtight lids. The containers are labeled properly and the water samples are handed over to the State level Water Testing Laboratory of Tamilnadu Water Supply and Drainage (TWAD) Board, 24 hours from the time of collection. One of the important parameters for drinking water and water used for other purposes is total dissolved solids. ${ }^{13}$ The increase and decrease of the concentration of TDS in groundwater have a direct relationship with the rainfall and water level changes. The infiltrated rainwater diluted the concentration of TDS and the fluctuation in the quality is observed. The $\mathrm{pH}$ value plays a vital role in determining the acidic or alkaline nature of water and widely used for domestic, agricultural and industrial uses. ${ }^{14}$ The contribution of fluoride concentration in the water is primarily due to the chemical composition of the rock formation. Apart from the other physical and chemical parameters, the health hazards parameters such as TDS, Fluoride and Nitrate have been given more priority as it affects the human health system. While considering human nutrition, fluoride is important for the development of bones. Fluoride concentration in water must be $1.5 \mathrm{mg} / \mathrm{L}$ which is the allowable limit. When this value is higher in groundwater, it develops skeletal fluorosis, tooth disorders, deformation in knee joints, etc. The most important criteria for determining the usage of water for consumption and other supplies is the hardness of the water. ${ }^{13}$ Table-1 shows the regular tests conducted in the water testing laboratory. ${ }^{9}$ 
Table-1: Tests Conducted in the Water Testing Laboratory

\begin{tabular}{c|c}
\hline Tests conducted in Lab & Parameters \\
\hline $\begin{array}{c}\text { The primary test is conducted within } 24 \mathrm{hrs} \\
\text { from the time of collection of samples }\end{array}$ & $\begin{array}{c}\text { Appearance, odor, turbidity, EC, pH, alkalinity, hardness, } \\
\text { calcium, ammonia, nitrate, Tidy's }\end{array}$ \\
\hline $\begin{array}{c}\text { Other regular parameters to be tested within } \\
\text { one week }\end{array}$ & $\begin{array}{c}\text { TDS, sodium, potassium, iron, manganese, nitrate, chloride, } \\
\text { fluoride, sulfate, phosphate, magnesium, silica }\end{array}$ \\
\hline
\end{tabular}

\section{Water Quality Parameters}

\section{RESULTS AND DISCUSSION}

The physical and chemical examination for different parameters has been carried out for 6 samples collected from different locations within the study area. The test results were compared with the permissible limits as per IS 10500:2012. There was a slight deviation in some of the physio-chemical parameters such as Turbidity, TDS, Alkalinity, Hardness, Calcium, and Iron. Table-2 shows the test results obtained from TWAD Board Water testing laboratory for various samples. The permissible limits as per are 10500:2012 is shown in the table which will be helpful in identifying the deviation in the values of certain physical and chemical parameters.

Table-2: Test Results for Various Samples

\begin{tabular}{|c|c|c|c|c|c|c|c|c|}
\hline \multirow{2}{*}{ S. No. } & \multirow{2}{*}{ Parameters, mg/L } & \multicolumn{6}{|c|}{ Sample } & \multirow{2}{*}{$\begin{array}{c}\text { IS } 10500: \\
2012 \\
\begin{array}{c}\text { Permissible } \\
\text { limit }\end{array}\end{array}$} \\
\hline & & 1 & 2 & 3 & 4 & 5 & 6 & \\
\hline \multicolumn{9}{|c|}{ PHYSICAL EXAMINATION } \\
\hline 1 & Turbidity NT Units & 0.3 & 0.5 & 0.2 & 0.6 & 0.4 & 6.8 & 5 \\
\hline 2 & Total dissolved Solids & 790 & 693 & 1211 & 2264 & 1560 & 1245 & 2000 \\
\hline 3 & $\begin{array}{c}\text { Electrical Conductivity Micro } \\
\mathrm{mho} / \mathrm{cm}\end{array}$ & 1129 & 990 & 1730 & 3234 & 2228 & 1779 & - \\
\hline
\end{tabular}

\begin{tabular}{|c|c|c|c|c|c|c|c|c|}
\hline \multicolumn{9}{|c|}{ CHEMICAL EXAMINATION } \\
\hline 4 & $\mathrm{pH}$ at $25^{\circ} \mathrm{C}$ & 7.35 & 7.43 & 7.12 & 7.49 & 7.39 & 7.56 & $6.5-8.5$ \\
\hline 5 & Ph. Alkalinity & 0 & 0 & 0 & 0 & 0 & 0 & - \\
\hline 6 & Total Alkalinity & 264 & 292 & 440 & 650 & 440 & 312 & 600 \\
\hline 7 & Total Hardness & 340 & 200 & 364 & 910 & 630 & 408 & 600 \\
\hline 8 & Calcium & 91 & 56 & 101 & 252 & 168 & 112 & 200 \\
\hline 9 & Magnesium & 27 & 14 & 27 & 67 & 50 & 31 & 100 \\
\hline 10 & Sodium & 112 & 112 & 195 & 323 & 229 & 177 & - \\
\hline 11 & Potassium & 11 & 10 & 19 & 32 & 23 & 17 & - \\
\hline 12 & Iron & 0 & 0 & 0 & 0 & 0 & 1.26 & 1.0 \\
\hline 13 & Manganese & 0 & 0 & 0 & 0 & 0 & 0 & 0.3 \\
\hline 14 & Free Ammonia & 0.23 & 0 & 0 & 0 & 0 & 0 & 0.5 \\
\hline 15 & Nitrite & 0.12 & 0.24 & 0.10 & 0.08 & 0.07 & 4.46 & - \\
\hline 16 & Nitrate & 21 & 33 & 35 & 19 & 6 & 4 & 45 \\
\hline 17 & Chloride & 194 & 107 & 274 & 625 & 425 & 365 & 1000 \\
\hline 18 & Fluoride & 0.62 & 0.57 & 0.48 & 0.72 & 0.78 & 0.84 & 1.5 \\
\hline 19 & Sulphate & 30 & 49 & 39 & 99 & 75 & 46 & 400 \\
\hline 20 & Phosphate & 0.42 & 0.48 & 0.52 & 0.56 & 0.47 & 1.27 & - \\
\hline 21 & Tidy's Test 4 hrs. & 0.40 & 0.32 & 0.36 & 0.32 & 0.32 & 0.40 & - \\
\hline
\end{tabular}


The physical and chemical parameters were in permissible limits for the sample collected from Urapakkam and Guduvancheri regions. The parameters such as TDS, alkalinity, hardness, and calcium were higher than the permissible limits in Potheri region. The sample from Kattankulathur was high in total hardness and the sample from Maraimalai Nagar was more turbid than permissible and had high iron content.

\section{Rainfall and Water Quality}

The quality of water varies for rainfall with respect to the different input and location. ${ }^{15}$ The annual average rainfall of the study area has been analyzed from 2012-2018. As per the report from Tamilnadu Water Supply and Drainage Board, regions such as Chengalpattu, Guduvancheri, Kattankulathur, Vandalur, etc., are in a semi-critical category based on the extraction of groundwater (as on March 2013). Rainfall is necessary for maintaining the groundwater level. Table-3 shows the average rainfall (in mm) observed at different Raingauge stations placed in and around Kancheepuram District. According to the average rainfall data for the study region, it is evident that there is a decrease in the amount of rainfall after the flood (2015). Since there is frequent extraction, the water quality will be affected, and it will also be difficult to maintain the water table.

The maximum value of different physical and chemical parameters for different year post flood has been compared in Table-4. Physiochemical parameters were compared from 2015 to 2019 and were found to have a deviation from past data to the present. Parameters such as $\mathrm{pH}$, fluoride, nitrate, and sulfates have low value and parameters such as TDS, alkalinity, hardness, iron, and chloride have increased considerably compared to the previous data.

Figure-1 shows the comparison of different parameters of water quality data collected during 2015-2016 with permissible limits. Figure- 2 shows the comparison of different parameters of water quality data collected during 2017-2018 with permissible limits. Figure-3 shows the comparison of different water quality parameters collected during 2019 with permissible limits.

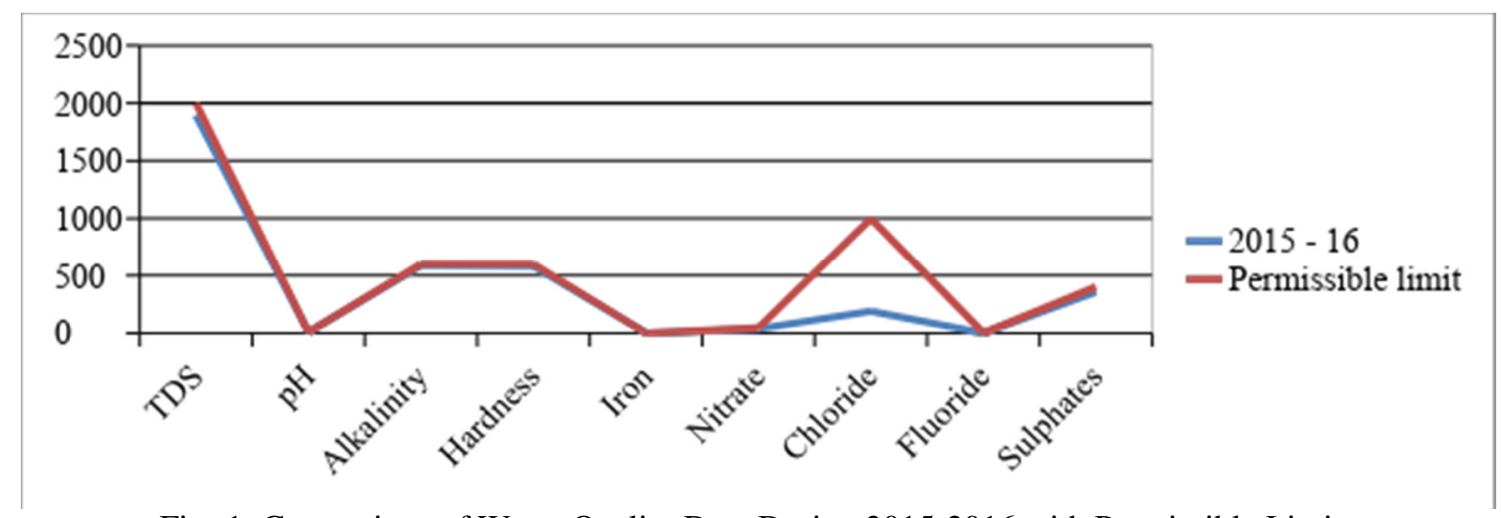

Fig.-1: Comparison of Water Quality Data During 2015-2016 with Permissible Limits

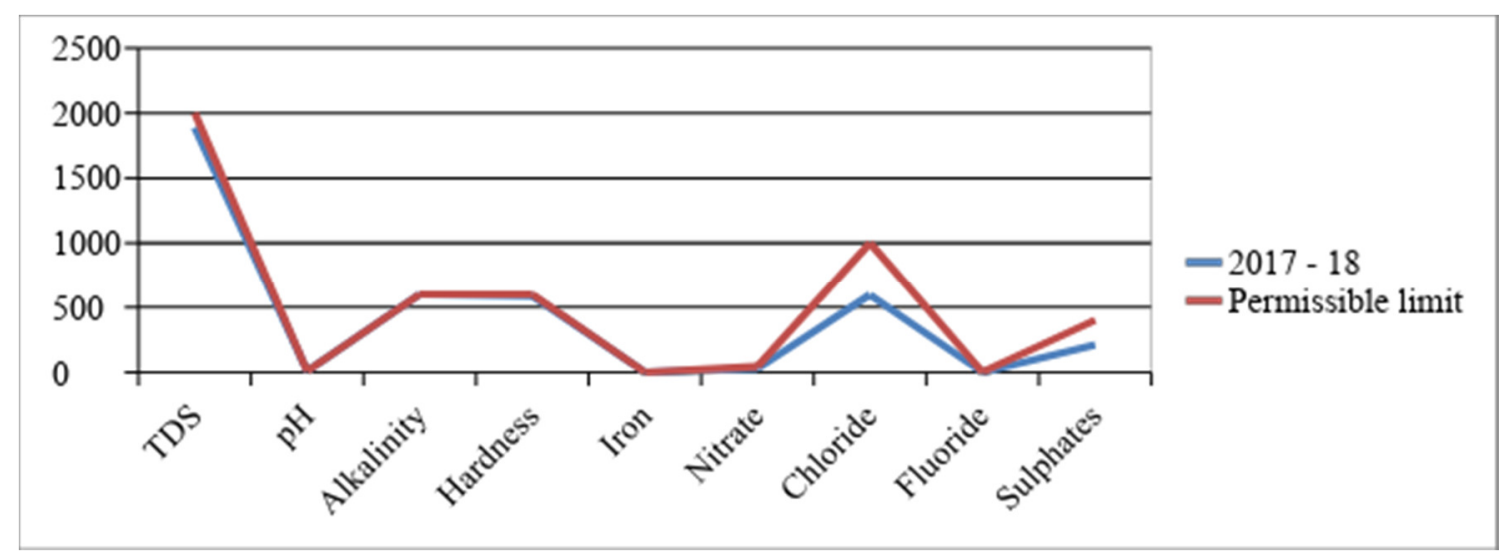

Fig.-2 Comparison of Water Quality Data during 2017-2018 with Permissible Limits 
RASĀYAN J. Chem.

Vol. 12 | No. 2 |849 - 854| April - June | 2019

Table-3: Average Rainfall for Kancheepuram District (in mm)

\begin{tabular}{c|c|c|c|c|c|c|c|c}
\hline \multirow{2}{*}{ S.No. } & \multirow{2}{*}{ Raingauge Station } & \multicolumn{7}{|c}{ Total Rainfall for the Year in $\mathrm{mm}$} \\
\cline { 3 - 8 } & & 2012 & 2013 & 2014 & 2015 & 2016 & 2017 & 2018 \\
\hline 1 & Chengalpattu & $1,375.40$ & 788.16 & 591 & $2,626.70$ & 828.3 & $1,202.90$ & $1,004.80$ \\
\hline 2 & Cheyyur & 375.8 & 516.02 & 764.1 & $2,023.90$ & 420.7 & 438.99 & 394.45 \\
\hline 3 & Kalpakkam & 903.76 & 642.1 & 3.4 & 0 & 0 & 0 & 0 \\
\hline 4 & Kancheepuram & 779.94 & $1,028.67$ & 911.6 & $2,264.30$ & $1,481.91$ & $1,948.90$ & $1,132.10$ \\
\hline 5 & Kelambakkam & 804.4 & 911.14 & $1,101.80$ & $1,802.60$ & $1,131.00$ & $1,360.90$ & 877 \\
\hline 6 & Maduranthagam & 736 & 931.7 & 629.15 & $1,778.00$ & 700.8 & 958 & 716.1 \\
\hline 7 & Mahabalipuram & $1,136.70$ & $1,033.14$ & 898.4 & $2,534.74$ & $1,166.70$ & $1,168.60$ & $1,063.14$ \\
\hline 8 & Sriperumbudur & 872.92 & $1,028.90$ & 793.31 & $2,395.10$ & $1,107.90$ & $1,135.60$ & 749.2 \\
\hline 9 & Tambaram & 800.87 & 857.88 & $1,041.43$ & $2,527.40$ & 933 & 567.8 & 338.32 \\
\hline 10 & Thirukazhukundram & 0 & 243.6 & 749.1 & $2,712.20$ & $1,184.10$ & 944.7 & $1,048.10$ \\
\hline 11 & Tiruporur & 0 & 0 & 0 & 0 & 0 & 136.4 & 826.57 \\
\hline 12 & Uthiramerur & 962 & 915.2 & 709.82 & $2,362.00$ & 843.05 & $1,564.50$ & 805.85 \\
\hline 13 & Walajabad & 0 & 0 & 0 & 0 & 0 & 46.3 & 309.97 \\
\hline \multicolumn{2}{|c|}{ District Average } & 672.91 & 684.35 & 630.24 & $1,771.30$ & 753.65 & 882.58 & 712.74 \\
\hline
\end{tabular}

(Source: REVENUE ADMINISTRATION, DISASTER MANAGEMENT, AND MITIGATION DEPARTMENT)

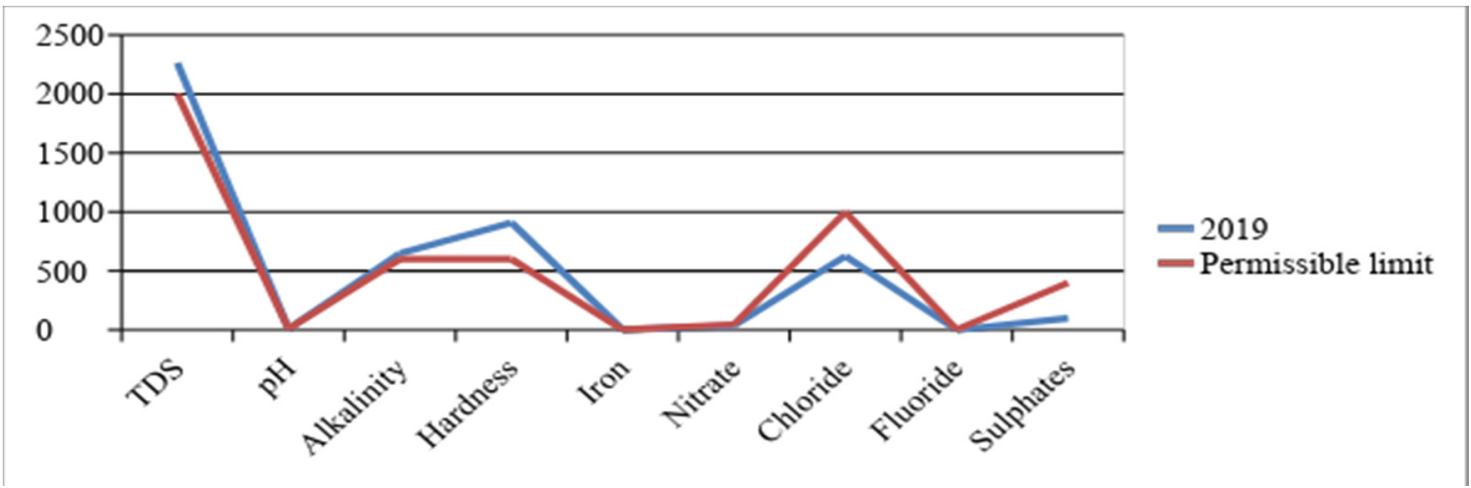

Fig.-3 Comparison of Water Quality Data during 2019 with Permissible Limits

Table-4: Comparison of Physiochemical Parameters Post Flood

\begin{tabular}{|c|c|c|c|c|c|}
\hline \multirow[b]{2}{*}{ S. No. } & \multirow{2}{*}{ Parameters (mg/l) } & \multicolumn{3}{|c|}{ Values during the year } & IS 10500:2012 \\
\hline & & $2015-16$ & $2017-18$ & 2019 & Permissible limit \\
\hline 1 & Total dissolved Solids & 1897 & 1890 & 2264 & 2000 \\
\hline 2 & $\mathrm{pH}$ & 8.48 & 8.5 & 7.56 & $6.5-8.5$ \\
\hline 3 & Total Alkalinity & 588 & 600 & 650 & 600 \\
\hline 4 & Total Hardness & 580 & 588 & 910 & 600 \\
\hline 5 & Iron & 1 & 1 & 1.26 & 1.0 \\
\hline 6 & Nitrate & 38 & 28 & 35 & 45 \\
\hline 7 & Chloride & 190 & 596 & 625 & 1000 \\
\hline 8 & Fluoride & 1.5 & 1.5 & 0.84 & 1.5 \\
\hline 9 & Sulphates & 360 & 210 & 99 & 400 \\
\hline
\end{tabular}

\section{CONCLUSION}

Water quality is very important for the life of human being and livestock as well. The different physiochemical parameters such as TDS, pH, Alkalinity, Hardness, Iron, Nitrate, Chloride, Fluoride, and Sulphates, etc., were analyzed for the water quality. The results reveal that most of the parameters are exceeding the permissible limits. During flood event ie., in 2015-2016, the water quality parameters were within the permissible limit. Since the sediment was washed away by the flood, the quality was improved. 
Later in 2017-2018, there was a deviation in some parametric values and in 2019 the water quality deteriorated to some extent due to human activities. The health hazard parameters such as TDS, Nitrate, and Fluoride must be carefully analyzed in order to assess human health risk. The value of TDS, alkalinity and hardness have increased post flood and other such parameters are within the limits stipulated by WHO standards. Since the TDS and hardness values are higher, it causes ill effects on human. These parameters must be brought within the permissible limits by certain water treatment processes which reduce the risk to a certain extent. Further study can be done to identify the remedial measures for better water quality in the region.

\section{REFERENCES}

1. M. Moni, Climate Change and Its Impact on Water Resources in India, 2004

2. K. Jothivenkatachalam, A. Nithya, S. Chandra Mohan, Rasayan J. Chem., 3(4), 649(2010)

3. S. Shrestha, F. Kazama, Environmental Modelling and Software, 22(4), 464(2007), DOI:10.1016/J.ENVSOFT.2006.02.001

4. N. C. Mondal, V. K. Saxena, V. S. Singh, African Journal of Environmental Science and Technology, 2(9), 265(2008)

5. D. Garg, R. Kaur, D. Chand, S. Kumar Mehla, R. Singh, Rasayan J. Chem., 1(4), 743(2008)

6. M. Senthilkumar, L. Elango, Journal of Earth System Sciences, 122(2), 419(2013)

7. R. Ghazavi, A. B. Ali, S. Eslamian, Water Resources Management, 26, 1651(2012), DOI:10.1007/s11269-012-9977-4

8. P. G. Whitehead, R. L. Wilby, R. W. Battarbee, M. Kernan, A. J. Wade, Hydrological Sciences Journal, 54(1), 101(2009), DOI:10.1623/hysj.54.1.101

9. M. Kamalanandhini, R. Nagalakshm, S. Srividhya, V. P. Golda Percy, International Journal of Pure and Applied Mathematics, 118(20), 4343(2018)

10. V. Bharadwaj, Dhruv, S. Singh, Environmental Earth Science, 63, 383(2011), DOI:10.1007/s12665010-0709-x

11. Y. Chen Ching, Y. Heng Lee, M. Ekhwan Toriman, M. Abdullah, B. Bin Yatim, Sustainable Water Resource Management, 1, 97(2015), DOI:10.1007/s40899-015-0009-4

12. S. D. Jadhav, R. S. Sawant, A. G. Godghate, S. R. Patil, R. S. Patil, Rasayan J. Chem., 5(2), 246 (2012)

13. S. Mitharwal, R. D. Yadav, R. C. Angasaria, Rasayan J. Chem., 2(4), 920(2009)

14. H. L. Yadav, A. Janal, Rasayan J. Chem., 11(1), 46(2018), DOI:10.7324/RJC.2018.1111961

15. Colin Neal, Richard Skeffington, Margaret Neal, Roger Wyatt, Heather Wickham LH and NH, Hydrology and Earth System Sciences, 8(4), 601(2004)

[RJC-5232/2019] 